\title{
女子学生の理工系選択における高等学校の 教科「数学」の寄与に関する考察
}

An Investigation of the Influence of Mathematics in a High School for Female Students in Choosing Scientific or Technological Direction

$\begin{array}{lll}\text { 田 美 佐 }{ }^{* 1} & \text { 青 柳 美 輝*1 } & \text { 平 田 典 子※1 } \\ \text { Misa TANAKA } & \text { Miki AOYAGI } & \text { Noriko HIRATA-KOHNO }\end{array}$

\section{1.はじめに}

平成 26 年版の科学技術白書 ${ }^{1)}$ が文部科学省から刊行 された。 そこには科学技術イノベーション推進を担う のは「人」であり,「多様な」人材が活躍できる環境の 整備が急務であると述べられている．多様性を性別の 観点から鑑みると, 我が国の女性技術者・研究者の割 合は, 先進国の中において相変わらず最下位であるこ とが平成 26 年版男女共同参画白書 ${ }^{2)}$ の第 5 章 $1-5-9$ 図:研究者に占める女性割合の国際比較にある(図 1 ).

特に理工系における女性の割合が低いことが先の平 成26年版科学技術白書 ${ }^{1)}$ 第 1 部第 2 章 p. $96,1-2-19$ 図にある（図 2 ）。日本の理工系大学の学部生の男女 比については, 大学入学の時点で既に女子学生の割合 が諸外国に比べて大きく劣るという残念な現状が以前 よりあり ${ }^{3)}$, 平成24年10月の国立教育政策研究所によ る理系文系進路選択に関わる意識調査においても, 理 学系および工学系では女子の進路選択率は未だに少な

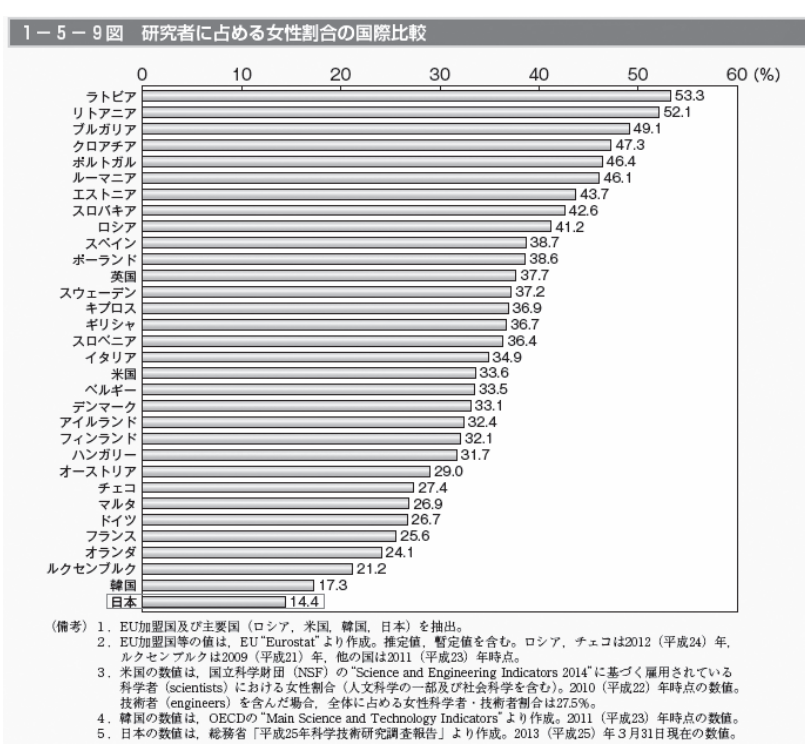

図 1 平成26年版男女共同参画白書 ${ }^{2)}$ より転載

2014 年 7 月 23 日受付 ※1 日本大学理工学部
いようである ${ }^{4)}$ 。これらには様々な要因があろうが, 我々は大学の理工学部数学科教員として, 数学という 科目が女子学生の理工系選択に及ぼす影響や寄与につ いての考察を試みたいと考える．以前にも類似の考 察 ${ }^{5), 6)}$ を実施したが, 今回はそれに比較して特に過 去になかった回答項目を追加解析し, 数学の教科内容 に対する女子高校生の興味そのものが，学年を重ねる に従って相当に変化すると思われた分析結果を報告す る. 加えて今回は, 以下に述べる男女共同参画学協会 連絡会という組織のアンケート解析結果報告書から, その新しい動機付けを得たことを申し述べる.

男女共同参画学協会連絡会とは, 自然科学系および 理工系の学会・協会（平成26年 8 月現在, 52 学協会が正 式加盟) から成り, 主に理工系研究者の男女共同参画书 よび女性技術者・女性研究者の環境改善に資する活動 をおこなっている組織である．5年ごとに日本の理工 系の分野に打ける男女共同参画の実態調査を実施して いるが，その「第三回科学技術系専門職の男女共同参 画実態調查」(通称, 第三回大規模アンケート) は平成 24年11月から 12 月にかけて実施されたものであり, 延 べ16,314名（男性11,958名, 女性4,356名）の回答総数が あった。この調査は理工系の男女参画の実態を明らか にするものとして政府の白書や報告書等にも引用され ているようである。この第三回大規模アンケート解析 報告書 $^{7)} \mathrm{p} .23$ の図 1.35 および 1.36 のグラフは質問 15 「小中高時代の進路選択に影響を与えたもの」は何で

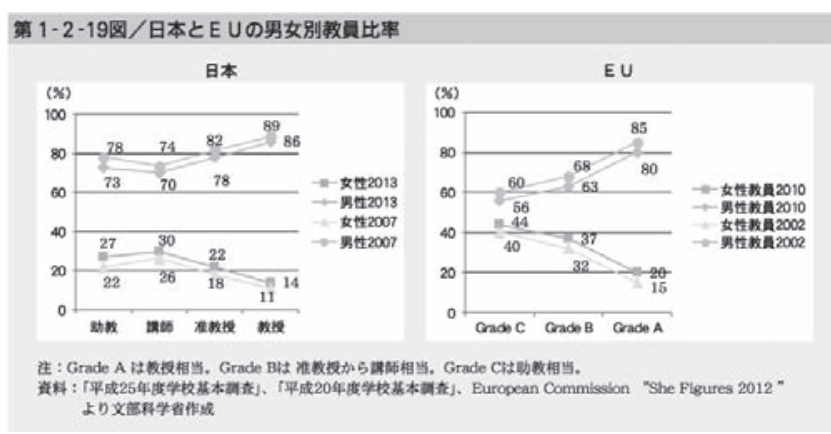

図 2 平成 26 年版科学技術白書 ${ }^{1)}$ より転載 
あるかという問いかけに対する回答であったが，その 回答者は理工系の技術者掞よび研究者であるため, 概 ね理工系選択理由としてとらえられる。このうち特に 男女の回答数の差の大きい項目を引用し列記してみよ う. 男子のほうが女子より回答率の高かった回答項目 は「幼少時に自然にわいた興味」（男性約 $62 \%$ ・女性約 $58 \%$ ），「書籍やテレビ番組」(男性約44\%・女性約 $38 \%$ ) であり，この二つの回答項目が，男女共に突出した高 い回答率を得ていた。またこれ以外に男子のほうが女 子より回答率の高かった回答項目には「科目の成績の 良し悪し」(男性約27\%・女性約 $25 \%$ ）がある。これに 対し, 女子のほうが男子より回答率の高かった回答項 目は「興味深い授業内容」(男性約 $25 \%$ ・女性約31\%) 「先生との交流」（男性約 $23 \%$ ・女性約 27\%）「家族，親 戚からの影響」（男性約 $22 \%$ ・女性約 $31 \%$ ）であった。 筆者らが経験則として常々感じているのは，女子学生 は学校の教員など身近な人間の影響を強く受ける傾向 があるように思えること，そして理工系への興味や進 路について考える時期が, どうも男子学生よりも遅い ように感じられることの二点であり，上記の第三回大 規模アンケート回答は, 我々の日頃の感想と一致する 部分がある. 高等学校の数学と女子学生の理工系選択 との関連を洗い出すための考察 ${ }^{5)}$, 6) に続くアンケー 卜調查の解析ではあるが，本稿においては特に，上記 の男女差の大きな理由を踏まえての視点に基づいた課 題意識のもとに設問 1 から設問 4 を再分析し，また設 問 5 から設問 7 の回答項目を新たに追加して解析をお こなった。

\section{2. 調査内容}

平成24年11月および平成25年11月に我々のアンケー 卜調査を実施した。本稿で分析をおこなう設問を以下 に列記しょう。設問 5 ・設問 6 ・設問 7 の回答グラフ は本稿において始めて紹介する（表 1 ).

アンケート調查対象は中高一貫私立女子高等学校一 校の高校 1 年生 $~ 3$ 年生であり, 平成 24 年度と 25 年度 の各年度において 1 回ずつ延べ 762 人である. 回答をグ ラフにして分析を試みた。高校 3 年生については理系 クラスの生徒数が計 103 人, 文系クラスの生徒数が計 132人である（表 2 ).

\section{3. 調査結果の解析とその内容}

図 3 と図 4 は設問 1 の回答, 図 5 と図 6 は設問 2 の 回答, 図 7 と図 8 は設問 3 の回答である。平成 24 年の 高校 1 年次が図 3 と図 5 と図 7 の回答者であり, その 1 年後の平成 25 年の高校 2 年次（ほほ同じ生徒の集団 である）が図 4 と図 6 と図 8 の回答者である. 図 3 に おいては数学に対する印象を「得意」としていた生徒 が, 1 年後の平成 25 年の高校 2 年次では減少し, 図 4 において「得意とは言えないが嫌いではない」「不得

\section{表 1 アンケートの設問抜粋}

\begin{tabular}{|c|c|}
\hline 回答項目 & $\begin{array}{l}\text { あなたは中学校や高等学校で学んでいる「数学」 } \\
\text { という教科についてどのような印象を持っていま } \\
\text { すか. } \\
\text { (1) 得意 } \\
\text { (2) 得意とは言えないが, 嫌いではない } \\
\text { (3) 不得意であり, しかも嫌い }\end{array}$ \\
\hline 回答項目 & $\begin{array}{l}\text { 設問 } 1 \text { の回答の印象が確定したのは, いつ頃から } \\
\text { でしょうか. } \\
\begin{array}{llll}\text { (1) 小学生の頃 } & (2) \text { 中学生の頃 } & \text { (3) 高校入学後 }\end{array}\end{array}$ \\
\hline 回答項目 & $\begin{array}{l}\text { 設問 } 1 \text { で「不得意であり, しかも嫌い」と答えた } \\
\text { 方へ, 主要と思われる理由 } 1 \text { つを選んでレを記 } \\
\text { 入してください. } \\
\text { (1) 数学の授業が理解できないから } \\
\text { (2) 試験などで良い成績が取れないから } \\
\text { (3) 数学の学習内容そのものに興味が持てないから } \\
\text { (4) その他 (記述式) }\end{array}$ \\
\hline 回答項目 & $\begin{array}{l}\text { 設問 } 1 \text { で「得意」あるいは「得意とは言えないが } \\
\text { 嫌いではない」と答えた方へ, 主要とわれる思わ理 } \\
\text { 由 } 1 \text { つを選んでください. } \\
\text { (1) 数学の授業が理解できるときがあるから } \\
\text { (2) 試験などで良い成績が取れたことがあるから } \\
\text { (3) 数学の学習内容そのものに興味を持てるとき } \\
\text { があるから } \\
\text { (4) その他 (記述式) }\end{array}$ \\
\hline 回答項目 & $\begin{array}{l}\text { 高校の数学の授業において, DVDやパワーポイ } \\
\text { ントなどのファイルをパソコンで映すなど各種の } \\
\text { 「画像」を取り入れた授業を行うと, より深く理 } \\
\text { 解できるようになるでしょうか. } \\
\text { (1) 数学の授業では「画像」による授業はわかり } \\
\text { やすいとは言えない } \\
\text { (2) 数学の授業でも時と場合に応じて「画像」を } \\
\text { 用いる授業は効果的 } \\
\text { (3) なるべく多くの数学の授業を「画像」を用い } \\
\text { ておこなった方が良い } \\
\text { (4) その他 (記述式) }\end{array}$ \\
\hline 設問 6 & 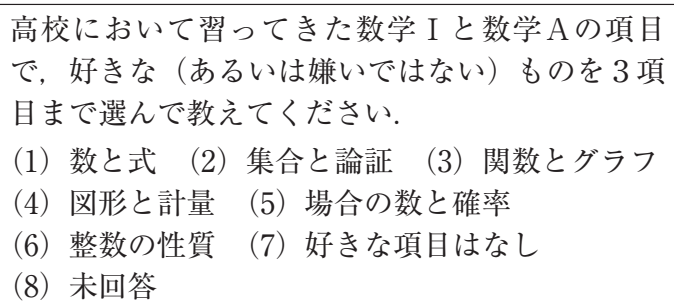 \\
\hline 回答項目 & $\begin{array}{l}\text { 女性研究者ロールモデルテキスト「女子こそサイ } \\
\text { エンス」を読んで, 次の意見のうち, どれに最も } \\
\text { 賛成できますか. 1つを選んでください. } \\
\text { (1) 理工系に大変興味を持った } \\
\text { (2) 理工系に少し興味を持った } \\
\text { (3) 理工系に興味を持てない } \\
\text { (4) 未回答 }\end{array}$ \\
\hline
\end{tabular}

表 2 調查対象の私立女子高等学校の生徒数

\begin{tabular}{||c|c|c||}
\hline 平成 24 年度 & 平成 24 年度 & 平成 25 年度 \\
\cline { 2 - 3 } 高校 1 年生 & 高校 3 年生 & 高校 2 年生 \\
\hline 2264 人 & 235 人 & 263 人 \\
\hline \hline 高 3 内訳 $:$ 文系 & 高 3 内訳 $:$ 理系 & 高 3 合計 \\
\hline 103 人 & 132 人 & 235 人 \\
\hline
\end{tabular}




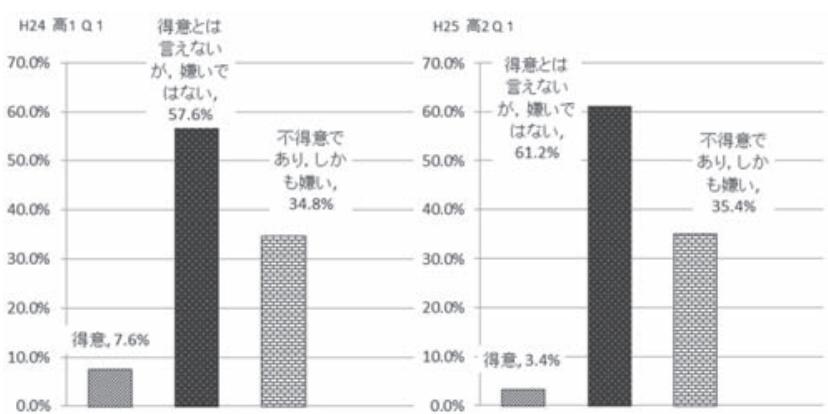

図 3 (左) 設問 1 の回答（H24年 高校 1 年生） 図 4 (右) 設問 1 の回答 (H25年 高校 2 年生)

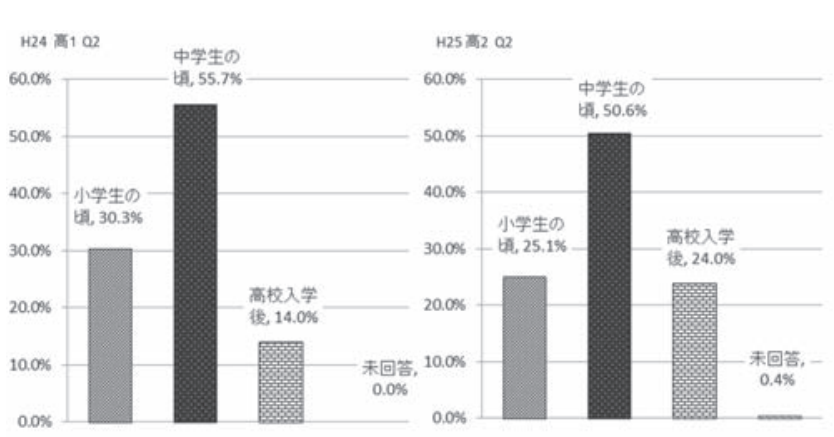

図 5 (左) 設問 2 の回答 (H24年 高校 1 年生) 図 6 (右) 設問 2 の回答 (H25年 高校 2 年生)

意でありしかも嫌い」が若干増加している．しかし図 3 から図 4 への変化よりも，設問 2 の回答である図 5 から図 6 への変化が大きい. 即ち数学に対する印象が 確定した時期が，「高校入学後」であると回答した生 徒が，大幅に増えている．数学の印象を「得意」とし た生徒の単純な減少と言うよりも，「得意」「得意では ないが，嫌いではない」「不得意であり，しかも嫌い」 という印象が交互に変化する現象が起きているように も思われる。抒そらくその理由としては高校 1 年次よ りも数学の高度な授業に接した高校 2 年生が, 具体的 な授業内容に実際に触れることによる意見の変化を起 こしたことなどが，例えば考えられよう。その理由を 詳しく調べるために, 以前の考察 ${ }^{5), 6)}$ に加えて追加調 查項目として問いかけた設問 5，6，7 を解析し，また 本稿の初めに述べた男女共同参画学協会連絡会第三回 大規模アンケートの「小中高時代の進路選択に影響を 与えたもの」という観点から各回答を考察することに した。

まず, 設問 1 において数学が「不得意であり，嫌い」 と回答した生徒に対し，その詳しい理由を問う設問 3 に対しては, 図 7 に示されるように高校 1 年次では「数 学の学習内容そのものに興味が持てない」が回答のト ップに位置している。図 8 は，ほぼその 1 年後の生徒 の集団の同じ設問に対する回答である. 図 7 から図 8 への変化はそれほど大きくはないが，やはり興味が持

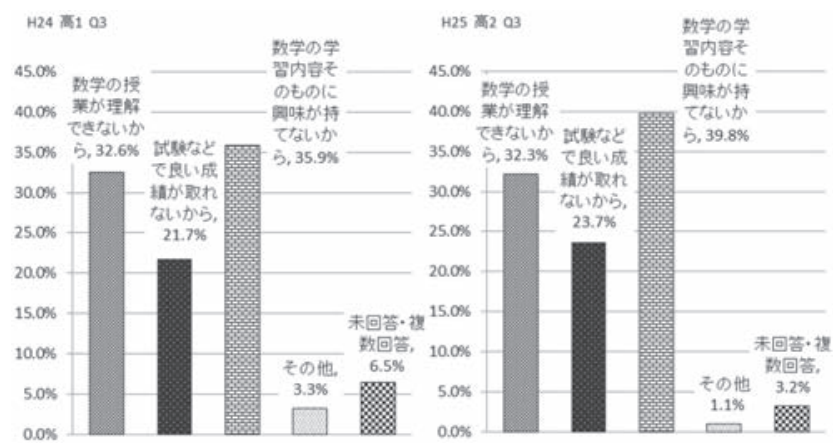

図 7 (左) 設問 3 の回答（H24年 高校 1 年生） 図 8 (右) 設問 3 の回答（H25年 高校 2 年生）

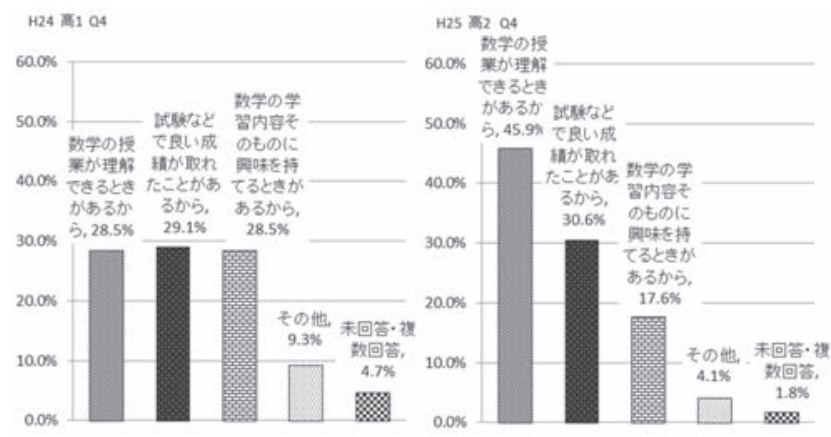

図 9 (左) 設問 4 の回答 (H24年 高校 1 年生) 図10 (右) 設問 4 の回答（H25年 高校 2 年生）

てなかった科目に対し, 成績, 理解といったキーワー ドが，ネガティブな反応への理由として若干の増加を 示していることは見て取れる.

さらに設問 1 において「得意」「得意ではないが, 嫌 いではない」と回答した生徒に対しては, 設問 4 を設け て, 数学へのポジティブな意見の拠りどころを問うて みた. 高校 1 年次の設問 4 に対する回答が図 9 であり, また概ねその 1 年後の同じ生徒集団に対する回答が図 10 である. 各回答の割合が高校 1 年次の図 9 において は, どれもほぼ同じくらいであったものに対し, 高校 2 年次では図 9 から図10へと大きく変化しており,「数 学の学習内容そのものへの興味」よりも，受験を意識 し始める高校 2 年次では相当に現実的であろう「数学 の授業が理解できるかどうか」という理由が, 占める 割合の最も大きい回答になっている.

これらを踏まえると, 高校 1 年次では, 数学にネガ ティブな反応を持つ生徒では「数学の学習内容そのも のに興味が持てない」が図 7 の最高数の回答になって いるので，まずはともあれ数学への興味を持たせられ るかどうか，という点が導入として必要であるとも考 えられよう. 次いでその同じ生徒集団の学年が進むに つれて, 数学にポジティブな反応を持つ生徒の側に急 激に増えた回答項目「数学の授業が理解できるときが あるから」という意識を, もしも高校 1 年次に数学に ネガティブな反応を持つ生徒に持ってもらえるとした 


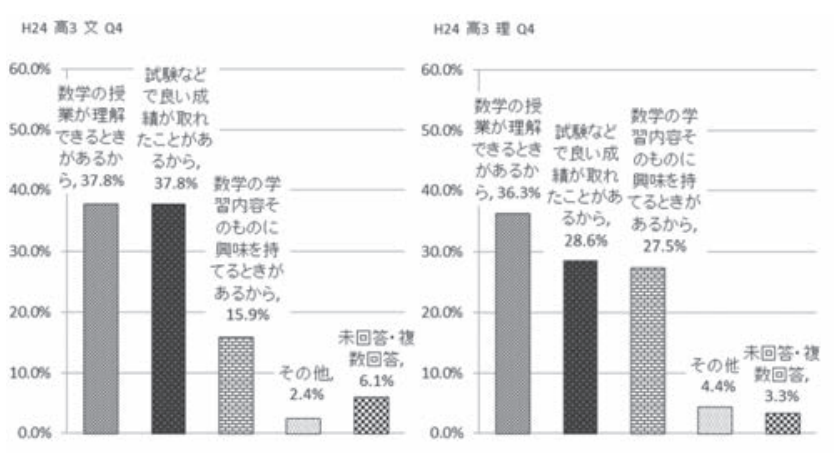

図11 (左) 設問 4 の回答（H24年 高校 3 年生 文系) 図12(右) 設問 4 の回答（H24年 高校 3 年生 理系)
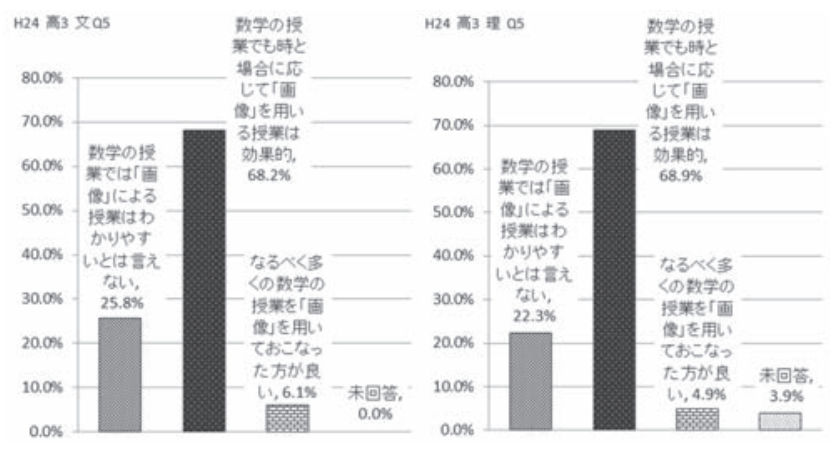

図13(左) 設問 5 の回答（H24年 高校 3 年生 文系) 図14(右) 設問 5 の回答（H24年 高校 3 年生 理系)

ら，おそらく基本的ではあろうが，数学そのものの理 解を促せる授業に努め, 「数学の授業が理解できるとき がある」ように仕向けられるようにすることが, 課題 解決法の一つなのかもしれないと観察される。

平成 24 年度高校 1 年生・平成 25 年度高校 2 年生とは 異なる集団である平成 24 年度の高校 3 年生に対して は，図11および図12で設問 4 の回答を示している，学 年全体もしくは文系選択者・理系選択者毎に分類した 結果のいずれにおいても，図11および図12のとおり， 「得意」「得意ではないが，嫌いではない」と回答した 生徒の主要理由が「数学の授業が理解できるかどうか」 になっている。䘜々ら高校 3 年生にもなると実際の 数学の授業内容そのもののレベルも上がっているので あろう。ここで面白いと感じ取れることは，文系選択 者と理系選択者とを比較すると, 数学の好き嫌いの理 由が「数学の学習内容そのものへの興味」に依存する 割合を示すデー夕において，大きな差が観察されるこ とである. 即ち, 理系の生徒における数学へのポジテ イブ意識は, 図12のように試駼結果や成績よりも，ど ちらかというと興味先行型であり, 文系のポジティブ 集団の理由は, 興味よりも現実の自分の教科成績が轪 引しているように，うかがえる。この理系クラスの回 答は, 男女共同参画学協会連絡会第三回大規模アンケ 一トにおいて女子の方が男子より回答率の高かった進 路選択理由「興味深い授業内容」に矛盾しない.

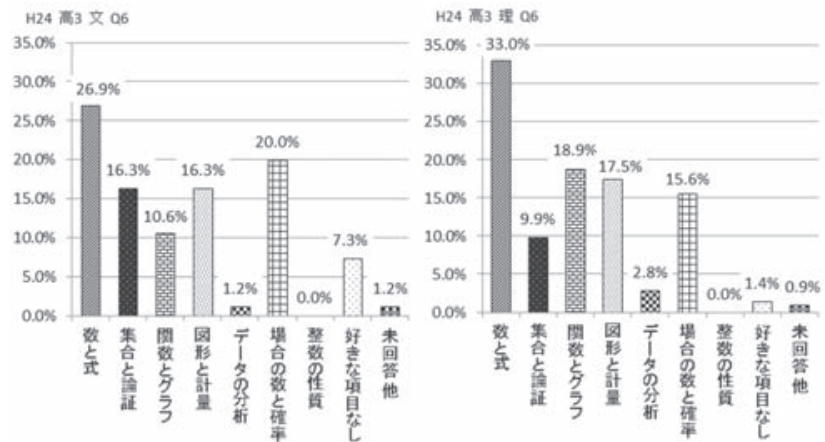

図15(左) 設問 6 の回答 (H24年 高校 3 年生 文系) 図16 (右) 設問 6 の回答（H24年 高校 3 年生 理系)

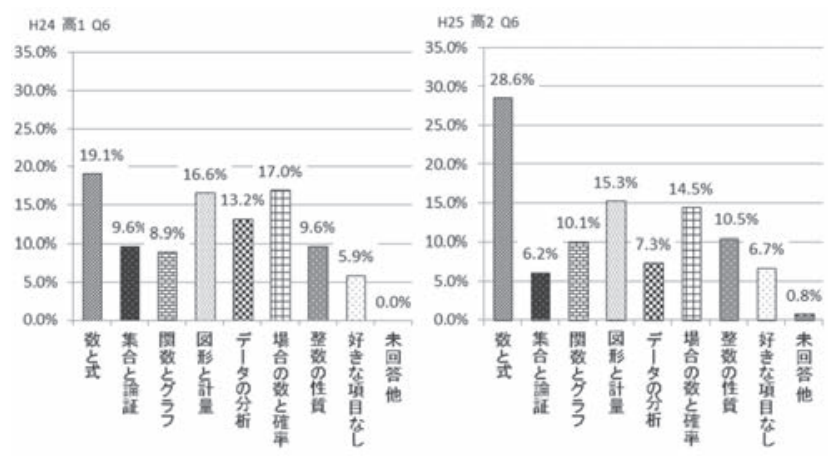

図17 (左) 設問 6 の回答（H24年 高校 1 年生） 図18(右) 設問 6 の回答（H25年 高校 2 年生）

さて，ここで新たに追加した設問の回答についての グラフを本稿に抢いて紹介しょう。まずアニメやマン ガに慣れた画像世代に対する授業方法の工夫に関して 調べるために設問 5 を問いかけた，対象は平成 24 年度 の高校 3 年生であり, 文系選択者・理系選択者に分け ての回答分布を調べたところ, 文系回答の図13と理系 回答の図14には殆ど違いが見られなかった。

そこで数学のどのような内容が「理系受け」するの かを調べたいと思い, 設問 6 を問うた。高校 1 年生の 数学の内容である数学 $\mathrm{I}$ と数学 $\mathrm{A}$ の項目で, 好きな (あ るいは嫌いではない）ものを 3 項目まで選んで答えて もらうという設問 6 の回答を上記に図示しょう。

図15は高 3 文系, 図16は高 3 理系の回答であり,こ れらにおいて整数の性質の回答数がゼロになっている のは, カリキュラム改正のため高 $3 に$ 該当項目の学習 履歴がないためである. そのうえで代数的な「数と式」 や多分野の融合を俯瞰する力を問われる「関数とグラ フ」が高 3 理系に人気のあることが分かる。いわば数 学らしいと言えるような分野への好みが, 上級生ほど 際立つのであろうか. 図17は高 1 の回答, 図18はその ほぼ同じ集団が高 2 になったときの回答であり，高 1 に比べて「数と式」が高 2 で増加しているのは, 例え ば数式の扱いに慣れたためなのかもしれない.「集合と 論証」は高 1 ・高 2 ではさほど人気がないが, 高 3 文 系で好まれていることから, 年齢を経るに従い解釈が 

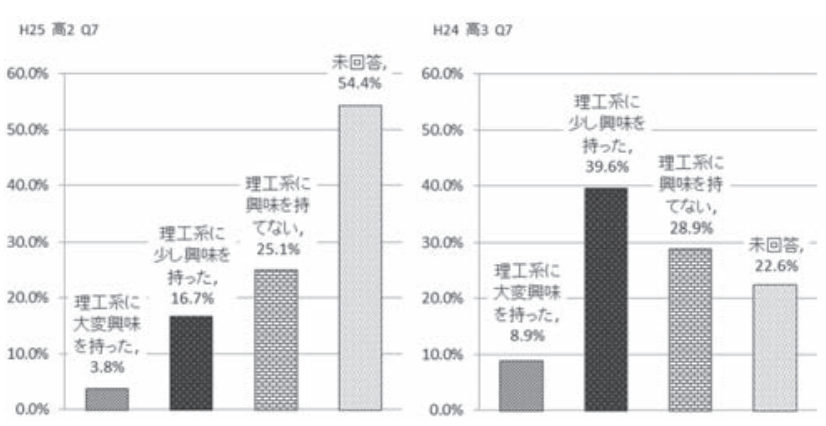

図19 (左) 設問 7 の回答（H25年 高校 2 年生） 図20(右) 設問 7 の回答（H24年 高校 3 年生 $)$

媣まる項目という見方もできよう。これは「集合と論 証」の特質にも沿っている。「好きな項目なし」につい て, 高 2 と高 3 文系の回答では大きな差が見られない のに対し, 高 3 理系で低くなっているのは, 救いであ る.

最後の設問 7 においては，筆者らの所属機関の女性 研究者の紹介冊子「女子こそサイエンス」の読後の感 想を問うた。この冊子は女子学生の理工系進路選択支 援の意図のもとに作成された。高校 2 年生の回答であ る図 19 と高校 3 年生の回答である図 20 を比べると, 高 校 3 年次に理工系に興味を持ったという回答が多く, また未回答数も少ないことが分かる．将来を真剣に考 える高校 3 年生というタイミングに合わせた情報提供 を身近な人の紹介等を介して行うならば，それは理工 系選択の推奨に極めて効果的なのかもしれない.

\section{4.おわりに}

第 1 節にて述べた男女共同参画学協会連絡会第三回 大規模アンケート解析報告書での進路選択理由におい て特に女子に顕著であった「興味深い授業内容」「先生 との交流」「家族, 親戚からの影響」という回答を裏付 けられるように, 興味深い授業内容の具体的項目や口 ールモデルの影響に関して調べることが本稿のアンケ 一トの動機の一つであった，実際には男子生徒と女子 生徒に同じ設問を問いかけたり, 長い時間をかけて追 跡しなければ分からないことが多々あることは承知し ている. しかし女子ならではの理工系選択理由として は何があるのか, そして年齢に応じてどのような変化 をするのかを調べ, 報告させて頂いた次第である，興
味深い授業内容の具体的項目から, 数学らしい項目が 好まれているように感じられることは，これからおお いに期待できる点であろう. 理工系の女性技術者を育 てることは日本において必然になろうが, 諸外国に比 して引けを取らないような女子の理工系選択状況が見 られる状況になって欲しいと願いながら, 筆を置く。

\section{謝辞}

本稿の研究は, 平成24～25年度日本大学理事長特別 研究「キャリアウェイ〜理系女子学生のキャリア教育 と活躍促進のための環境整備に関する研究」の助成を 受けたものである.

\section{参 考 文 献}

1 ) 文部科学省 : 平成 26 年版科学技術白書, Webペー ジ, http://www.mext.go.jp/b_menu/hakusho/ html/hpaa201401/1340515.htm

2 ）内閣府男女共同参画局：平成26年版男女共同参 画白書, 第 5 章, p.90, 2014年 6 月, Webページ, http://www.gender.go.jp/about_danjo/white paper/h26/zentai/pdf/h26_genjo3.pdf

3 ) 文部科学省: 平成18年版科学技術白書, 第 2 章 第 4 節, 第 1-2-68図, Webページ, http://www. mext.go.jp/b_menu/hakusho/html/hpaa 200601/001/002/0402.htm

4 ）国立教育政策研究所：理系文系進路選択に関わる 意識調査, p.173, 2012年10月, Webページ, https:// www.nier.go.jp/kaihatsu/pdf/zokuseichi-report. pdf

5 ) 青柳美輝, 田中美佐, 平田典子 : 数学に対する女子 学生の興味確定時期の調査アンケート解析, 数学 教育学会春季年会発表論文集, 255-257, 2014年 3 月

6 ) 第三回平成 $24-25$ 年度日本大学理事長特別研究 「キャリアウェイー理系女子学生のキャリア教育 と活躍促進のための環境整備に関する研究」シン ポジウム講演, 2014年 3 月

7 ) 男女共同参画学協会連絡会 : 第三回科学技術系専 門職の男女共同参画実態調査解析報告書, 2013年 8月, Webページ, http://www.djrenrakukai.org/ enquete.html 